\title{
Pathotype and Genetic Shifts in a Population of Phytophthora sojae Under Soybean Cultivar Rotation
}

S. Stewart, Plant Protection, National Agricultural Research Institute (INIA), Colonia, Uruguay; and N. Abeysekara and A. E. Robertson, Department Plant Pathology and Microbiology, Iowa State University, Ames 50011

\begin{abstract}
Stewart, S., Abeysekara, N., and Robertson, A. E. 2014. Pathotype and genetic shifts in a population of Phytophthora sojae under soybean cultivar rotation. Plant Dis. 98:614-624.

Changes in pathotype structure of Phytophthora sojae populations have been attributed to deployment of race-specific resistant $R p s$ genes in soybean that have been incorporated into commercial cultivars to reduce losses due to Phytophthora root and stem rot. To test this hypothesis, a cultivar rotation study was established from 2007 through 2010 in microplots at a site in Iowa with no history of soybean cultivation. All microplots were inoculated with $P$. sojae isolate PR1, race 1 (vir 7) prior to planting in year 1 . Six rotations were tested: (i) continuous planting of a $P$. sojae-susceptible cultivar, (ii) continuous planting of a cultivar with high partial resistance to the pathogen, (iii) continuous planting of a cultivar with the Rps $1 \mathrm{k}$ gene, (iv) annual rotation of a susceptible with a resistant cultivar, (v) annual rotation of a partially resistant cultivar with a cultivar with the Rps 1k gene, and (vi) 4-year rotation of cultivars with $R p s 1 \mathrm{k}, 1 \mathrm{c}, 3 \mathrm{a}$, and $1 \mathrm{k}$ genes in year one, two, three, and four, respectively. The diversity of 121 isolates of $P$. sojae that were recovered by baiting from soil samples collected from the experiment were assessed using pathotyping and eight microsatellite markers, and compared with PR1. Changes in pathotype and multi-

locus genotypes (MLGs) were recorded at the second sampling date, indicating that $P$. sojae has the ability to evolve quickly. In total, 14 pathotypes and 21 MLGs were recovered over the 4-year experiment, and only 49 and $22 \%$ of the isolates had the same pathotype and MLG, respectively, as PR1. The number of isolates of $P$. sojae recovered varied among rotations, with more isolates recovered from rotations that included a cultivar with partial resistance. Gain of virulence was detected on Rps 1a, 1b, 1c, 1d, and 3a and was not dependent on rotation. Using simple-sequence repeat analysis, 10 alleles that were different from those of PR1 were detected throughout the 4-year period. Cultivar rotation affected the genetic structure of the $P$. sojae population. Recovery of isolates with different MLGs, genotypic diversity $(G=4.7)$, and gene diversity $(\mathrm{UHe}=0.45)$ were greater under continuous rotation with partial resistance. Phytophthora root and stem rot causes economic losses in the north-central region of the United States annually. An improved understanding of the effect of Rps gene deployment on $P$. sojae diversity would lead to improved management practices and reduced losses.
\end{abstract}

Phytophthora sojae is an oomycete that causes Phytophthora stem and root rot (PRR) on soybean. The disease has been managed primarily through the use of resistant cultivars with single resistance genes (Rps). Fifteen known Rps genes in soybean confer resistance to PRR $(15,23,59)$, and some, such as Rps 1a, Rps 1c, and $R p s 1 \mathrm{k}$, have been incorporated into commercial soybean cultivars (25). This host-pathogen system is governed by a gene-forgene system $(14,22)$; thus, for every Rps gene that has been identified in soybean, there is a corresponding avirulence (Avr) gene. The effectiveness of a resistance gene depends on its ability to recognize the pathogen's corresponding Avr gene. Evolving Avr genes have enabled $P$. sojae to adapt to specific Rps genes and, consequently, the effectiveness of these genes has been progressively lost as new races or pathotypes of the pathogen have appeared. In the 1980s, Rps 1a and Rps 1c were the most common Rps genes incorporated into commercial soybean varieties in the north-central region of the United States to protect soybean from losses caused by PRR. When races of the pathogen compatible on these genes became prevalent (25), Rps $1 \mathrm{k}$ became the most common resistance gene used in soybean varieties throughout the northern Midwest (1,51) but, by the late 1990s, there were reports of races of $P$. sojae causing disease on Rps $1 \mathrm{k}$. In Iowa, Rps $1 \mathrm{k}$ is currently the most common resistance gene used, followed by Rps $1 \mathrm{c}$, but the increasing prevalence of race 25 (virulence formula 1a, $1 \mathrm{~b}, 1 \mathrm{c}, 1 \mathrm{k}, 7)(44)$ has prompted incorporation of Rps 6 into

Corresponding author: A. E. Robertson, E-mail: alisonr@iastate.edu

Accepted for publication 16 November 2013.

http://dx.doi.org/10.1094/PDIS-05-13-0575-RE

(C) 2014 The American Phytopathological Society germplasm for Iowa (47). Durability of Rps effectiveness in the field has been estimated at 8 to 20 years $(9,14,25)$.

Variability in $P$. sojae has been assessed traditionally through a virulence test using a set of soybean differentials. In all, 7 to 14 soybean lines, each with one Rps gene to $P$. sojae, and a line with no Rps genes (susceptible) are used to characterize races or pathotypes of $P$. sojae $(11,22)$. More than 55 described races of $P$. sojae have been identified on the basis of compatible (susceptible) and incompatible (resistant) reactions on these differential lines $(11,12)$. Originally, a race number was given to a pathotype of $P$. sojae with a specific virulence formula; however, as new virulence gene combinations or pathotypes of the pathogen continued to emerge $(1,4,5,10,11,14,20,29,31,32,34,36,39,42,43,49,51,61,66$, $68,69)$ this race classification system was discouraged $(69)$. Potentially, there are $32,768\left(2^{\mathrm{N}}\right.$, where $N=15$ Rps genes) possible virulence combination or races, leading researchers to now describe pathotypes rather than continue naming new races. Since 1948 , when the first $P$. sojae race was identified, the number of pathotypes has increased dramatically and there are now more than 200 known pathotypes of this pathogen (12). Complexity of $P$. sojae pathotypes also seems to have increased with time (14). For example, almost $20 \%$ of the isolates surveyed in Michigan in the mid1990s had virulence to 10 or more Rps genes (31). These continuous changes in virulence of the pathogen are called pathotype (or race) shifts.

Another strategy that has been used in breeding programs to manage PRR is partial resistance. Partial resistance is a form of incomplete resistance that is expressed in the $P$. sojae-soybean system as a reduced level of root rot. Partial resistance does not exhibit the boom-and-bust cycle characteristic of major resistance genes (40). It is polygenic, equally effective across all pathotypes (40), and limits the lesion growth rate of the disease , allowing the host to tolerate the infection better when compared with a fully 
susceptible host $(12,21,60)$. Thus, partial resistance should be more stable than single-gene resistance because of the lack of selection pressure imposed on the pathogen (53). However, because partial resistance is harder to breed for and introduce into desired germplasm, this strategy has not been as widely used as singlegene resistance to reduce loses to PRR.

Changes in the pathotype structure of populations of $P$. sojae have been attributed to deployment of specific resistance genes $(29,49,51,68)$, which result in selection of resistant pathotypes. An alternative way to prolong the life of a resistance gene in the field is to rotate major resistance genes temporally and spatially (40) or rotate with cultivars with high partial resistance. These strategies have the potential to disrupt selection and, therefore, reduce the rate at which one particular pathotype increases its frequency within a population. In the tobacco (Nicotiana tabacum) $-P$. nicotianae pathosystem, rotation of single-gene resistance and cultivars with high levels of partial resistance resulted in a reduction in black shank disease incidence and also minimized race shifts of the pathogen (57).

The goal of this research was to determine whether cultivar rotation could be used to effectively minimize pathotype shifts in a population of $P$. sojae and, thus, prolong the life of a resistant soybean cultivar in the field. We monitored pathotype and genetic shifts in a $P$. sojae-inoculated site within a 4-year soybean-cultivar rotation experiment. We used conventional pathotype characterization (12) to detect shifts in pathotypes and microsatellite marker (simple-sequence repeat [SSR]) analysis (10) to monitor genotypic changes in the population.

\section{Materials and Methods}

Site selection. In 2007, 24 microplots were established on a field site with no known history of soybean cultivation at the Iowa State University Northern Research and Demonstration Farm, near Kanawha. Each microplot was approximately $75 \mathrm{~cm}$ in diameter and was surrounded by plastic lawn edging to minimize cross contamination among plots. Soil samples from each microplot were collected when the microplots were established and were assayed three times to test for a $P$. sojae using seedling baiting method (50). Furthermore, the presence or absence of $P$. sojae in each soil sample was also tested using a $P$. sojae-primer specific (PSOJF1 and PSOJR1) polymerase chain reaction (PCR)-based detection method (6). DNA was extracted from the soil with the FastDNA spin kit for soil (MP Biomedicals), and DNA of P. sojae, a Pythium sp., and $P$. cactorum were used as controls.

Field experiment. A soybean-cultivar rotation study was planted in the established microplots. The experiment consisted of six rotations arranged in a complete randomized block design with four repetitions. Rotations included cultivars with different sources of resistance to $P$. sojae: susceptible 'Sloan', with no rps genes and low partial resistance (13); 'Stine 2402', with no rps genes and moderate to high partial resistance (13); '2834RR', with Rps $1 \mathrm{k}$ and low partial resistance (13); 'Williams 79' with Rps 1c (11); and 'L83-570' with Rps 3a (11). Rotations were defined as follows: rotation 1, continuous planting of Sloan; rotation 2, annual rotation of Sloan and $2834 \mathrm{RR}$; rotation 3, annual rotation of $2834 \mathrm{RR}$ and Stine 2402; rotation 4, 4-year rotation of 2834 RR, Williams 79, L83-570, and 2834 RR in year one, two, three, and four, respectively; rotation 5, continuous planting of Stine 2402; and rotation
6, continuous planting of $2834 \mathrm{RR}$ (Table 1). Sowing dates for the 4-year period varied from 3 to 17 June and no seed treatment was used.

Each microplot was artificially inoculated in year 1 (2007) of the study with a single-zoospore isolate, $P$. sojae PR1, which is virulent on Rps 7 (race 1) and had been grown for 10 days on sterile sorghum grain. PR1-infested sorghum $\left(50 \mathrm{~cm}^{3}\right)$ was sprinkled directly on top of the sown soybean seed ( 25 seeds/microplot). An additional $200 \mathrm{~cm}^{3}$ of the inoculum was broadcast over the top of each microplot once the seed had been covered with soil. In the second year of the study (2008), each microplot was inoculated a second time with a slurry of 10 plates of PR1 grown on diluted V8 which had been blended with 1.0 liters of sterile distilled water. At sowing, $50 \mathrm{~cm}^{3}$ of the slurry was poured over the top of the sown seed. Each year, after seedling emergence, microplots were thinned to 20 plants and flooded four to eight times throughout the season, depending on the year, to provide favorable soil moisture for infection of the soybean plants by $P$. sojae. In order to monitor pathotype and genetic changes in the PR1, soil samples (80 to 100 g) were collected from each microplot 2 to 3 weeks after planting and immediately prior to harvest. Soil samples were assayed to isolate $P$. sojae using a seedling baiting method (50).

Seedling baiting method. In all, 50 to $60 \mathrm{~cm}^{3}$ of soil was added to 340-g Dart (Dart Container Corporation) polystyrene cups, prepunctured with three holes at the bottom. Cups were placed in growth chamber at $25^{\circ} \mathrm{C}$ and a 16 -h day. The soil samples were moistened and incubated in the cups inside a nylon bag for 2 weeks, previous to the bioassay to induce oospore germination (50). Six seeds of the susceptible Sloan soybean were planted in each cup to bait $P$. sojae from the soil sample. Three to four days after planting, the pots were flooded for $24 \mathrm{~h}$. Thereafter, every 3 days, pots were watered until flooded and the water was allowed to slowly drain from the bottom (9). Each soil sample was baited three times. When symptoms of PRR were evident on seedlings (brown hypocotyl lesion or collapsed hypocotyls), the plants were removed from soil, washed with running tap water, dried on a sterile paper towel, and placed under PBNIC agar in a petri dish. Isolates of $P$. sojae were confirmed by their growth pattern on PBNIC (16) and morphology of sporangia developed in sterile water after the use of Chen-Zentmeyer's salt-wash solution technique (50)

Purification and storage of isolates. Purification of $P$. sojae isolates was done using monozoospores obtained by Chen-Zentmeyers' salt-wash solution technique (50). Purified isolates of $P$. sojae were stored in sterile distilled water at room temperature until further use.

Pathotype characterization. Pathotypes of $P$. sojae were determined with the hypocotyl inoculation technique using a 15-cultivar differential set $(9,11,17,50)$. The following standard soybean lines or varieties, each having a specific resistant $R p s$ gene, were grown in trays in the greenhouse: 'L88-8470' (Rps 1a), 'L77-1863' (Rps 1b), Williams 79 (Rps 1c), 'L99-3312' or plant introduction (PI) 103091 (Rps 1d), 'Williams 82' (Rps 1k), 'L82-1449' (Rps 2), L83570 (Rps 3a), 'L91-8347' (Rps 3b), 'L92-7857' (Rps 3c), 'L852352' (Rps 4), 'L85-3059' (Rps 5), 'Altona' or 'L89-1581' (Rps 6), 'L93-3258' or 'Harosoy' (Rps 7), PI 399073 (Rps 8), and 'Williams' (universal susceptible). Ten 1-week-old seedlings of each variety were inoculated by making a slit with a syringe in the

Table 1. Soybean cultivar rotations planted in microplots at the Iowa State University Northern Research Farm from 2007 through 2010

\begin{tabular}{|c|c|c|c|c|c|c|}
\hline \multirow[b]{2}{*}{ Year } & \multicolumn{6}{|c|}{ Rotation $^{\mathbf{a}}$} \\
\hline & 1 & 2 & 3 & 4 & 5 & 6 \\
\hline 2007 & Sloan & Sloan & $2834 \mathrm{RR}$ & $2834 \mathrm{RR}$ & Stine 2402 & $2834 \mathrm{RR}$ \\
\hline 2008 & Sloan & $2834 \mathrm{RR}$ & Stine 2402 & Williams 79 & Stine 2402 & $2834 \mathrm{RR}$ \\
\hline 2009 & Sloan & Sloan & Stine 2402 & L83-570 & Stine 2402 & $2834 R R$ \\
\hline 2010 & Sloan & $2834 \mathrm{RR}$ & $2834 \mathrm{RR}$ & $2834 \mathrm{RR}$ & Stine 2402 & $2834 R R$ \\
\hline
\end{tabular}

a Cultivars and genes: Sloan, no rps genes and low partial resistance; 2834RR, with Rps 1k and low partial resistance; Stine 2402, with no rps genes and moderate to high partial resistance; Williams 79, with Rps 1c; and L83-570, with Rps 3a. 
hypocotyl and placing approximately 0.2 to $0.4 \mathrm{ml}$ of a slurry from a 7- to 10-day-old culture into the slit $(16,50)$. A plastic covering was placed over the tray for 12 to $16 \mathrm{~h}$ to keep the inoculum from drying. At 7 to 10 days after inoculation, PRR incidence was evaluated. Susceptible plants died or developed distinct symptoms of PRR, whereas resistant plants developed a hypersensitive reaction (slight necrotic lesion around the wound). The soybean differential was considered susceptible when at least 7 of 10 seedlings died. The test was repeated at least twice for each isolate and was done as soon as the isolates were purified.

DNA extraction. Genomic DNA was extracted from purified isolates grown in V8 broth using a cetyltrimethylammonium bromide procedure, as described by Stewart et al. (54). DNA was suspended in Tris-EDTA, concentration was measured using a Nanodrop ND-1000 Spectrophotometer and adjusted to $100 \mathrm{ng} / \mu \mathrm{l}$, and DNA was stored at $-20^{\circ} \mathrm{C}$ for SSR analysis.

Molecular genotypes. Eight microsatellite primer pairs-PS01, PS05, PS10, PS12, PS24, PS29, and PS33 (10)-were used to screen 121 isolates (Table 2). Forward fluorescent primers for Ps01, Ps16, Ps24, and Ps33 were labeled with 6-FAM dye and Ps05, Ps10, PS12, and Ps29 with HEX dye. Amplification was performed following the protocol of Stewart et al. (54) with the Biosystem 3730 Genetic Analyzer. GeneMapper Software 4.0 (Applied Biosystem) was used to size the alleles to the nearest base pair.

Data analyses. The number of alleles per locus, observed heterozygosity $(\mathrm{Ho})$, expected heterozygosity $(\mathrm{He})$, and Hardy-Weinberg equilibrium (HWE) for each locus were calculated using population genetic software GenAlEx 6 (46).

Index of association $\left(\mathrm{I}_{\mathrm{A}}\right)$ was calculated using the genetic data for each rotation in MultiLocus V1.3b (2). Genotypic diversity was estimated for each rotation using Stoddart and Taylor's $G$ index (55); however, to be able to compare indexes using populations of different sizes, $G$ was scaled by the expected number of genotypes for the smallest population size (26) with rarefaction curves using
Analytical Rarefaction (version 1.3; S. M. Holland, Analytical Rarefaction Software).

Genetic and pathotype differentiation using genotypic and binary distance among the six rotations were assessed using an estimate of differentiation $\left(\theta_{\mathrm{PT}}\right)$ described by Weir and Cockerham (64). Analysis of molecular variance (AMOVA) (19) was performed among the six rotations using software GenAlEx 6 (46). Significant levels were evaluated using 999 permutations. For the purpose of the pathotype AMOVA analysis, the interaction of $P$. sojae with the respective Rps gene of each soybean differential was considered a locus (avirulence locus) with two possible outcomes; compatible $=1$ or incompatible $=0$.

A dendrogram comparing the relatedness among the six cultivar rotations was created based on $P$. sojae allele frequencies and Nei's genetic distance, using unweighted pair-group method (UPGMA) with bootstrap values calculated on 100 UPGMA trees using SEQBOOT, GENDIST, NEIGHBOR, and CONSENCE in PHYLIP version 3.69 (J. Felsenstein, Department of Genetics, University of Washington, Seattle).

Correlation of individual by individual genetic distance matrices for the overall isolates in the experiment was calculated using codominant (genetic) and binary (pathotype) options in software GenAlEx 6 (46). The Mantel test for matrix correspondence was used to test the statistical relationship between the two distances using the same software.

\section{Results}

No $P$. sojae was recovered by baiting the soil samples collected from each microplot three times immediately prior to the setup of the experiment. A 130-bp band was amplified from soil samples from 3 of the 24 microplots using the specific primers for $P$. sojae (PSOJF1 and PSOJR1) (6) and the P. sojae and P. cactorum controls. Two additional baiting tests were done on the three soil samples but we were never able to isolate $P$. sojae. No visible disease symptoms were observed throughout the 4-year study.

Table 2. Loci, primers, and alleles based on approximate band sizes as determined by GeneMapper analysis for eight microsatellite loci on 121 isolates of Phytophthora sojae recovered from soil collected from a soybean cultivar-rotation study (2007 to 2010)

\begin{tabular}{|c|c|c|c|c|}
\hline Locus & Sequence motif in isolate $\mathrm{P6497}^{\mathrm{a}}$ & Primer $^{\mathbf{b}}$ & Label on forward primer & Allele size (bp) and designated letter \\
\hline PS01 & $(\text { GACACT })_{49}$ & PS01-F, PS01-R & 6 FAM & $419(\mathrm{~A}), \mathbf{4 2 5}(\mathrm{J}), \mathbf{4 3 1}(\mathrm{K})$ \\
\hline PS05 & $(\mathrm{TCAG})_{34}$ & PS05-F, PS05-R & HEX & $\mathbf{2 6 3}(\mathrm{A}), 339(\mathrm{~K}), 343(\mathrm{~L})$ \\
\hline PS10 & $(\mathrm{CAAAC})_{27}$ & PS10-F, PS10-R & HEX & 191(D),221(A),226(H) \\
\hline PS12 & $(\mathrm{GCTGTT})_{23}$ & PS12-F, PS12-R & HEX & $251(\mathrm{~B}), 257(\mathrm{C}), 310(\mathrm{~A})$ \\
\hline PS16 & $(\text { ATTAT })_{20}$ & PS16-F, PS16-R & 6 FAM & $405(\mathrm{C}), 470(\mathrm{~A}), 475(\mathrm{H})$ \\
\hline PS24 & $(\mathrm{CT})_{16}+(\mathrm{CT})_{3}$ & PS24-R, PS24-F & 6 FAM & 252(A) \\
\hline PS29 & $(\mathrm{TAC})_{15}$ & PS29-R, PS29-F & HEX & 249(B), 270(A) \\
\hline PS33 & $(\mathrm{AT})_{15}$ & PS33-R, PS33-F & 6 FAM & $250(B)$ \\
\hline
\end{tabular}

a Symbol: + indicates that two simple repeats were separated by other bases.

b Primer sequence detailed by Dorrance and Grunwald (10).

${ }^{\mathrm{c}}$ Letters in parentheses indicate alleles as named by Stewart et al. (54). Alleles in bold are the alleles present in PR1, the isolate used to inoculate the experiment. Genotype PR1: 425/431, 263/263, 221/221, 251/251, 470/470, 252/252, 249/249, and 250/250 for simple-sequence repeats PS01, PS05, PS10, PS12, PS16, PS24, PS29, and PS33, respectively.

Table 3. Number of isolates and pathotypes detected of Phytophthora sojae recovered from soil samples collected from a six-soybean cultivar rotation over 4 years (2007 to 2010)

\begin{tabular}{|c|c|c|c|c|}
\hline Rotation $^{\mathrm{a}}$ & $\begin{array}{l}\text { Number of isolates } \\
\text { of } P \text {. sojae recovered }\end{array}$ & $\begin{array}{l}\text { Number of pathotypes } \\
\text { of } P \text {. sojae detected }\end{array}$ & $\begin{array}{c}\text { Number of race } 1 \\
\text { isolates recovered }^{b}\end{array}$ & $\begin{array}{c}\text { Number of non-race } 1 \\
\text { isolates recovered }\end{array}$ \\
\hline 1 & 13 & 6 & 5 & 8 \\
\hline 2 & 34 & 7 & 13 & 21 \\
\hline 3 & 30 & 7 & 19 & 11 \\
\hline 4 & 7 & 2 & 3 & 4 \\
\hline 5 & 30 & 8 & 14 & 16 \\
\hline 6 & 7 & 3 & 5 & 2 \\
\hline Total & 121 & 14 & 59 & 62 \\
\hline
\end{tabular}

a Rotation sequences: 1 = continuous planting of a cultivar with no rps gene; 2 = annual rotation of a cultivar with no $r p s$ and a cultivar with $R p s$ 1k gene; $3=$ annual rotation of a cultivar with $R p s 1 \mathrm{k}$ gene and a partially resistant cultivar; $4=4$-year rotation of cultivars with $R p s 1 \mathrm{k}, 1 \mathrm{c}, 3 \mathrm{a}$, and $1 \mathrm{k}$ gene in year one, two, three, and four, respectively; $5=$ continuous planting of a cultivar with high partial resistance; $6=$ continuous planting of a cultivar with $R p s 1 \mathrm{k}$ gene.

${ }^{\mathrm{b}}$ Race 1 = virulent formula (7), identical race/pathotype as isolate PR1 use to inoculate the experiment.

${ }^{c}$ Non-race 1 included virulence formulas (1d), (1d,7), (1a,7), (2,7), (3b,7), (1c,7), (1d,2,7), (1a,1c,7), (1k,2,7), (1a,1c,2,7), (1a,1c,1d,7), and (1d,2,3b,7). 
Pathotypes. In total, 121 isolates of $P$. sojae belonging to 14 pathotypes were recovered from soil samples collected from the microplots from 2007 through 2010 (Table 3). The number of isolates recovered from each rotation over the 4 years varied, with most of the isolates being recovered from those rotations that included a cultivar with high partial resistance to P. sojae. Of the 121 isolates recovered, $49 \%$ belonged to the same pathotype as the original inoculated isolate (race 1; vir 7), and the prevalence of this pathotype was 38 to $71 \%$ among the rotations (Table 3 ). The remaining 62 isolates $(51 \%)$ were virulent on at least one and up to three additional Rps genes (Fig. 1). Of the 62 non-race 1 isolates, 55 belonged to one of seven pathotypes while six isolates were unique to a single pathotype. The most prevalent pathotype detected after vir 7 was vir 1a, 1c, and 7 (21 isolates).

New pathotypes were recovered as early as the second sampling date (fall of year 1; Table 4). During the first 2 years of the 4-year experiment, only one or two pathotypes that were different from PR1 were recovered from four of the six rotations whereas, in the third and fourth years, up to five new pathotypes were recovered from all rotations (Table 4). Altogether, the number of different pathotypes recovered from the six rotations ranged from two to eight. In each of rotation 3 and 5, isolates from eight pathotypes were recovered. Conversely, in rotations 4 and 6 , isolates belonging to only two and three pathotypes, respectively, were recovered over the course of the study (Fig. 1). Moreover, a lower number of isolates of $P$. sojae were recovered from rotations 4 and 6 over the 4 years (Fig. 1).

Of the 121 isolates recovered, 120 were virulent on $\operatorname{Rps} 7$; thus, $99 \%$ maintained the virulence of the original inoculated isolate (vir 7). More than $20 \%$ of the isolates recovered were virulent on Rps 1a and $1 \mathrm{c}$ while $15 \%$ were virulent on Rps $1 \mathrm{~d}$ and 2 . Only one of the isolates recovered was virulent on $R p s 1 \mathrm{k}$ and three were virulent on Rps 3b. Characterization of changes that may have occurred in the corresponding $A v r$ genes (Avr 1a, 1c, 1d, 1k, 2, and $3 \mathrm{~b}$ ) is currently in progress. No isolates that were compatible on Rps $1 \mathrm{~b}$, $3 \mathrm{a}, 3 \mathrm{c}, 4,5,6$, and 8 were detected over the course of the study (Fig. 2).

AMOVA's estimated variance for pathotype differentiation among rotations was $5 \%$ and the $\theta_{\mathrm{PT}}$ was low and nonsignificant $\left(\theta_{\mathrm{PT}}=0.047, P=0.059\right)$. No statistical difference in pathotype diversity was detected among rotations because $95 \%$ of the estimated variance was due to within rotation variations.

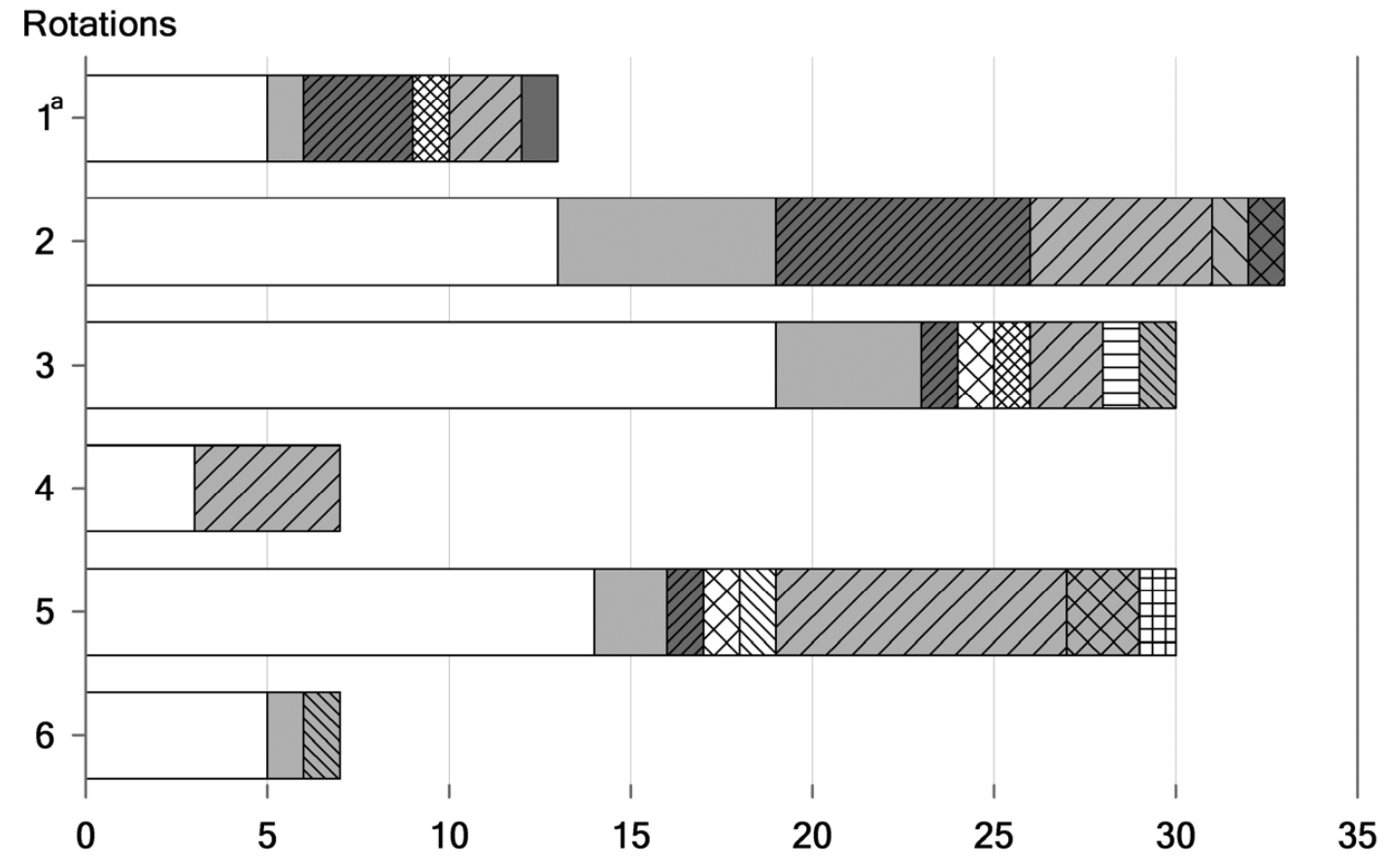

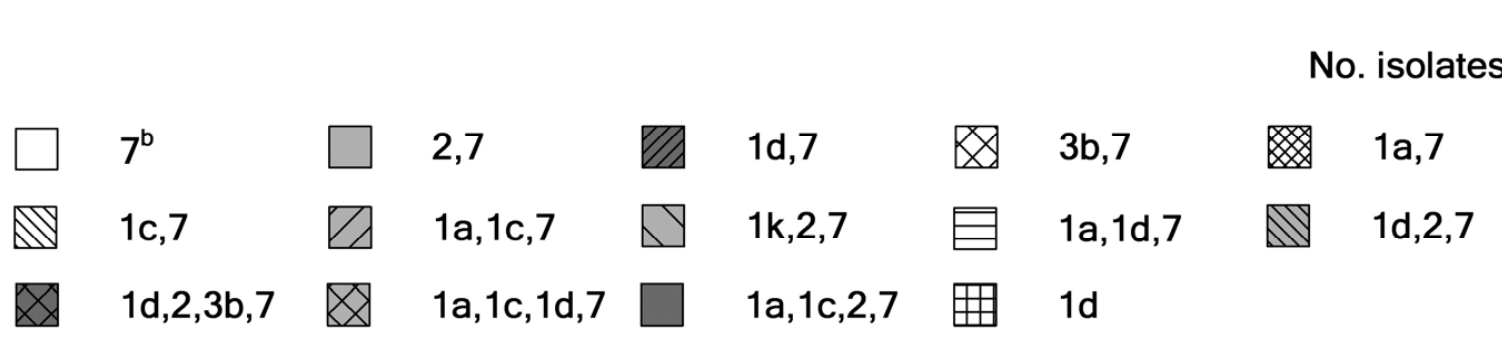

a rotation sequences: $1=$ continuous planting of a cultivar with no rps gene; $2=$ annual rotation of a cultivar with no rps and a cultivar with Rps 1k gene; $3=$ annual rotation of a cultivar with $R p s 1 \mathrm{k}$ gene and a partially resistant cultivar; $4=$ four year rotation of cultivars with $R p s 1 \mathrm{k}, 1 \mathrm{c}$, $3 \mathrm{a}$ and $1 \mathrm{k}$ gene in year one, two, three and four, respectively; $5=$ continuous planting of a cultivar with high partial resistance; $6=$ continuous planting of a cultivar with $R p s 1 \mathrm{k}$ gene. ${ }^{\mathrm{b}}$ identical race/pathotype as isolate PR1 used to inoculate the experiment.

Fig. 1. Number of isolates and pathotype diversity of 121 isolates of Phytophthora sojae recovered from soil from six-soybean-cultivar rotation in a 4-year study (2007 to 2010). 
SSR genotypes. Different size electropherogram peaks (fragment size) resulting from a microsatellite marker were considered different alleles. Each of the eight SSRs amplified one or two alleles per locus per isolate. Six of eight SSRs were polymorphic, with one to three alleles observed per locus in the 121 isolates recovered. In total, 19 alleles were identified among the 121 isolates, with an average of 1.8 alleles/loci. In total, 21 multilocus genotypes (MLGs) were identified within the 121 isolates from the experiment (Table 5), and 10 of these MLGs were unique to a single isolate. The remaining 11 MLG groups included 2 to 38 isolates. Only $22 \%$ of the isolates recovered over the 4-year period had the same MLG as the original PR1-inoculated isolate, while $38 \%$ had at least one new allele.

The average overall $\mathrm{Ho}$ in the 121 isolates recovered during the duration of the experiment was 0.037 but it ranged from 0.038 to 0.069 among rotations (Table 5). The UHe, analogous to gene diversity, was highest in rotations 4 and 5 (Table 5), meaning that two copies of a gene chosen at random in these rotations will have a higher probability of having different alleles than the rest of the rotations (41). The fixation index $(\mathrm{F})$ across rotations was 0.86 , and ranged from 0.80 to 0.92 among rotations (Table 5). Moreover, all

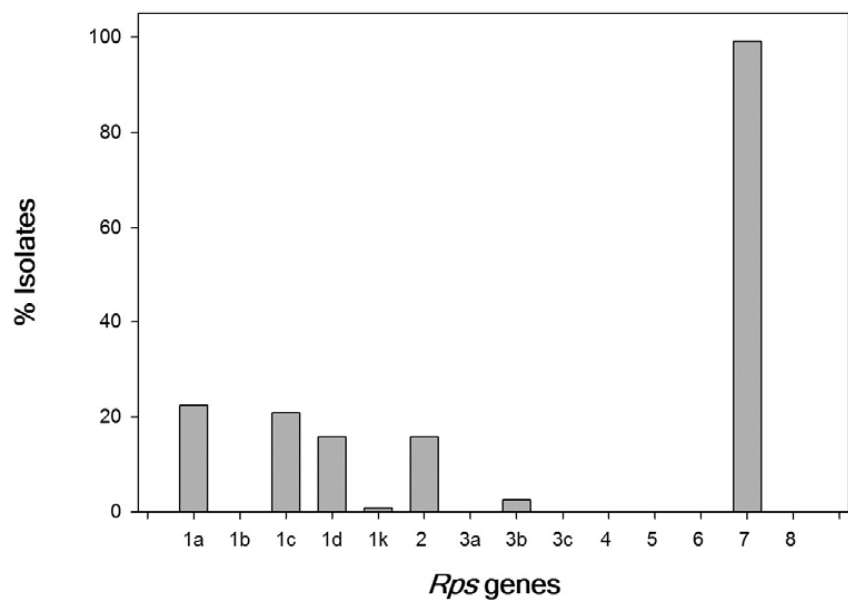

Fig. 2. Percentage of isolates of Phytophthora sojae $(n=121)$ recovered from soil samples collected from a 4-year soybean cultivar-rotation study that were compatible on soybean $R p s$ resistance genes. The site was $P$. sojae free, and was inoculated on year one with $P$. sojae race 1 , which is compatible on Rps 7.

Table 4. Virulence on Rps genes in soybean for isolates of Phytophthora sojae recovered from cultivar rotations from 2007 through $2010^{\mathrm{a}}$

\begin{tabular}{|c|c|c|c|c|c|c|c|}
\hline \multirow[b]{2}{*}{ Year } & \multirow[b]{2}{*}{ Season } & \multicolumn{6}{|c|}{ Rotations $^{\text {b }}$} \\
\hline & & 1 & 2 & 3 & 4 & 5 & 6 \\
\hline \multirow[t]{2}{*}{1} & Fall & $\ldots$ & $\ldots$ & $7(3)$ & $7(1)$ & $7(1)$ & \\
\hline & & $\ldots$ & $\ldots$ & $\ldots$ & $\ldots$ & $1 \mathrm{~d}(1)$ & $1 \mathrm{~d}, 2,7(1)$ \\
\hline \multirow[t]{5}{*}{2} & Spring & $\ldots$ & $7(2)$ & $7(6)$ & $\ldots$ & $\ldots$ & $\ldots$ \\
\hline & & $\ldots$ & $1 \mathrm{~d}, 2,3 \mathrm{~b}, 7$ (1) & $\ldots$ & $\ldots$ & & $\ldots$ \\
\hline & Fall & $7(2)$ & $7(2)$ & $\ldots$ & $\ldots$ & $7(2)$ & $\ldots$ \\
\hline & & 1d, 7 (3) & 1a, 1c, 7 (1) & $\ldots$ & $\ldots$ & $1 \mathrm{a}, 1 \mathrm{c}, 7$ (4) & $\ldots$ \\
\hline & & $\ldots$ & $\ldots$ & $\ldots$ & $\ldots$ & $1 \mathrm{a}, 1 \mathrm{c}, 1 \mathrm{~d}, 7$ (1) & $\ldots$ \\
\hline \multirow[t]{8}{*}{3} & Spring & $7(1)$ & $\dddot{7}(2)$ & $\dddot{7}(9)$ & $\ldots$ & $\dddot{7}(4)$ & $\dddot{7}(1)$ \\
\hline & & $1 \mathrm{a}, 1 \mathrm{c}, 7$ (1) & 1a, 1c, 7 (1) & $3 b, 7$ (1) & ... & $2,7(2)$ & $2,7(1)$ \\
\hline & & 1a, 7 (1) & $2,7(5)$ & 2,7 (4) & $\ldots$ & $3 b, 7$ (1) & $\ldots$ \\
\hline & & $\ldots$ & $1 \mathrm{k}, 2,7$ (1) & $1 \mathrm{a}, 1 \mathrm{~d}, 7$ (1) & $\ldots$ & $1 \mathrm{a}, 1 \mathrm{c}, 7$ (2) & $\ldots$ \\
\hline & & $\ldots$ & $\ldots$ & $1 \mathrm{a}, 1 \mathrm{c}, 7$ (2) & $\ldots$ & $\ldots$ & $\ldots$ \\
\hline & & $\ldots$ & $\ldots$ & $1 \mathrm{~d}, 2,7(1)$ & $\ldots$ & $\ldots$ & . \\
\hline & Fall & $\ldots$ & $7(1)$ & $7(1)$ & $\ldots$ & $7(3)$ & $7(4)$ \\
\hline & & $\ldots$ & $1 \mathrm{a}, 1 \mathrm{c}, 7$ (2) & 1a, 7 (1) & $\ldots$ & 1a, 1c, 7 (1) & $\ldots$ \\
\hline \multirow[t]{5}{*}{4} & Spring & $7(2)$ & $7(6)$ & $1 d, 7$ (1) & $7(2)$ & $7(4)$ & $\ldots$ \\
\hline & & $2,7(1)$ & 1d, 7 (7) & $\ldots$ & $1 \mathrm{a}, 1 \mathrm{c}, 7$ (1) & $1 \mathrm{c}, 7$ (1) & $\ldots$ \\
\hline & & $1 \mathrm{a}, 1 \mathrm{c}, 7(1)$ & $2,7(1)$ & $\ldots$ & $\ldots$ & $1 d, 7$ (1) & $\ldots$ \\
\hline & & $\ldots$ & $1 \mathrm{a}, 1 \mathrm{c}, 7$ (1) & $\ldots$ & $\ldots$ & $1 \mathrm{a}, 1 \mathrm{c}, 1 \mathrm{~d}, 7$ (1) & $\ldots$ \\
\hline & & $\ldots$ & $1 \mathrm{a}, 1 \mathrm{c}, 2,7$ (1) & $\ldots$ & $1 \mathrm{a}, 1 \mathrm{c}, 7(1)$ & $\ldots$ & $\ldots$ \\
\hline
\end{tabular}

${ }^{\text {a }}$ Shown are Rps genes and (in parentheses) number of isolates recovered that were virulent on the specified Rps gene.

${ }^{\mathrm{b}}$ Rotation sequences: 1 = continuous planting of a cultivar with no $r p s$ gene; 2 = annual rotation of a cultivar with no $r p s$ and a cultivar with Rps $1 \mathrm{k}$ gene; $3=$ annual rotation of a cultivar with $R p s 1 \mathrm{k}$ gene and a partially resistant cultivar; $4=4$-year rotation of cultivars with $R p s 1 \mathrm{k}, 1 \mathrm{c}, 3 \mathrm{a}$, and $1 \mathrm{k}$ gene in year one, two, three, and four, respectively; $5=$ continuous planting of a cultivar with high partial resistance; $6=$ continuous planting of a cultivar with Rps $1 \mathrm{k}$ gene.

Table 5. Genetic diversity statistics of 121 isolates of Phytophthora sojae recovered from soil samples collected from a soybean cultivar-rotation study done over 4 years (2007 to 2010)

\begin{tabular}{|c|c|c|c|c|c|c|c|}
\hline \multirow[b]{2}{*}{ Statistic $^{b}$} & \multicolumn{6}{|c|}{ Rotation $^{\mathrm{a}}$} & \multirow[b]{2}{*}{ Total } \\
\hline & 1 & 2 & 3 & 4 & 5 & 6 & \\
\hline Isolates $(n)$ & 13 & 34 & 30 & 7 & 30 & 7 & 121 \\
\hline Genotypes $(n)$ & 4 & 8 & 8 & 5 & 10 & 4 & 21 \\
\hline Ho & 0.038 & 0.039 & 0.069 & 0.048 & 0.052 & 0.048 & 0.037 \\
\hline UHe & 0.312 & 0.207 & 0.250 & 0.469 & 0.452 & 0.293 & 0.248 \\
\hline$F$ & 0.92 & 0.81 & 0.83 & 0.80 & 0.89 & 0.88 & 0.86 \\
\hline $\mathrm{I}_{\mathrm{A}}$ & 3.10 & 0.97 & 2.14 & 1.97 & 3.17 & 3.32 & 2.46 \\
\hline$P$ & 0.001 & 0.001 & 0.001 & 0.001 & 0.001 & 0.001 & 0.001 \\
\hline
\end{tabular}

a Rotation sequences: 1 = continuous planting of a cultivar with no rps gene; 2 = annual rotation of a cultivar with no rps and a cultivar with $R p s$ 1k gene; 3 = annual rotation of a cultivar with $R p s 1 \mathrm{k}$ gene and a partially resistant cultivar; $4=4$-year rotation of cultivars with $R p s 1 \mathrm{k}, 1 \mathrm{c}, 3 \mathrm{a}$, and $1 \mathrm{k}$ gene in year one, two, three, and four, respectively; $5=$ continuous planting of a cultivar with high partial resistance; $6=$ continuous planting of a cultivar with $R p s$ 1k gene.

${ }^{\mathrm{b}} \mathrm{Ho}=$ observed heterozygosity averaged across loci. UHe $=$ unbiased expected heterozygosity averaged across loci, $(2 n / 2 n-1)\left(1-\Sigma p^{2}{ }_{i}\right.$, where $p$ is the frequency of the $i$ th allele. $F=$ Wright's fixation index, where $F$ values close to zero are expected under random mating while values close to one indicate inbreeding. $\mathrm{I}_{\mathrm{A}}=$ index of association: $\mathrm{V}_{\mathrm{o}} /\left(\mathrm{V}_{\mathrm{e}}-1\right)$, where $\mathrm{V}_{\mathrm{o}}$ is the observed and $\mathrm{V}_{\mathrm{e}}$ the expected variance of $\mathrm{K}$ and $\mathrm{K}$ is equal to the number of loci at which two individuals differ. Frequent recombination events would have an expected $\mathrm{I}_{\mathrm{A}}$ value of zero. $P=$ probability of $\mathrm{I}_{\mathrm{A}}$ based on 1,000 randomizations; null hypothesis $=\mathrm{I}_{\mathrm{A}}$ does not differ from purely sexually outcrossing population. 
polymorphic loci deviated significantly from HWE when pooled across loci.

$\mathrm{I}_{\mathrm{A}}$ tests for recombination in a population and frequent recombination events would have an expected value $\mathrm{I}_{\mathrm{A}}$ of zero. The mean $\mathrm{I}_{\mathrm{A}}$ for the six rotations combined was moderate and significant $\left(\mathrm{I}_{\mathrm{A}}\right.$ $=2.46, P<0.001$ ) and ranged from 0.97 to 3.32 among the six rotations, indicating that non-random mating or asexual reproduction had occurred (Table 5).

Genotypic diversity $(G)$ was estimated with rarefaction to be able to compare rotations with different sample sizes. The $G$ across the six rotations was high $(G=4.6)$, considering that the maximum value is 7.0 (all MLGs differ from each other). For the individual rotations, however, $G$ was 3.7 to 4.7 (Fig. 3). Rotations 1 and 6 had the lowest $G$ (3.7) and the least number of MLGs (four) detected (Fig. 3). The maximum number of MLGs per rotation was 10, which was observed in rotation 5 (Fig. 3). The estimated variance for genotype differentiation among rotations as calculated by AMOVA was $8 \%$, and the $\theta_{\mathrm{PT}}$ was low but significant $\left(\theta_{\mathrm{PT}}=0.075\right.$, $P=0.044$ ). Thus, statistical differences were detected among rota- tions, even though $92 \%$ of the estimated variance was due to within-rotation variations. Only 4 of 15 pairwise $\theta_{\mathrm{PT}}$ values among rotations were significant (Table 6). In fact, isolates of $P$. sojae recovered from soil of rotation 2 were genetically different from those that were recovered from rotations 4 and 5. Furthermore, isolates of $P$. sojae recovered from rotation 3 were genetically different from those isolates of $P$. sojae that were recovered from soil samples collected from both rotation 5 and 4 .

The UPGMA analysis divided rotations into three subdivisions supported by two high bootstrap values. Rotations 2, 3, and 6 grouped together, rotations 4 and 5 grouped together, and rotation 1 remained by itself. Relatedness among rotations 4 and 5 was very high (bootstrap value $=98$ ) because the genetic distance based on the allele frequency between isolates recovered from rotating soybean with different resistance genes, and continuous partial resistance was similar (Fig. 4).

The correlation coefficient between genetic distance matrix (genotypes) and binary distance matrix (pathotype) was low ( $r=$ 0.23 ) but significant $(P=0.001)$, indicating a relationship between

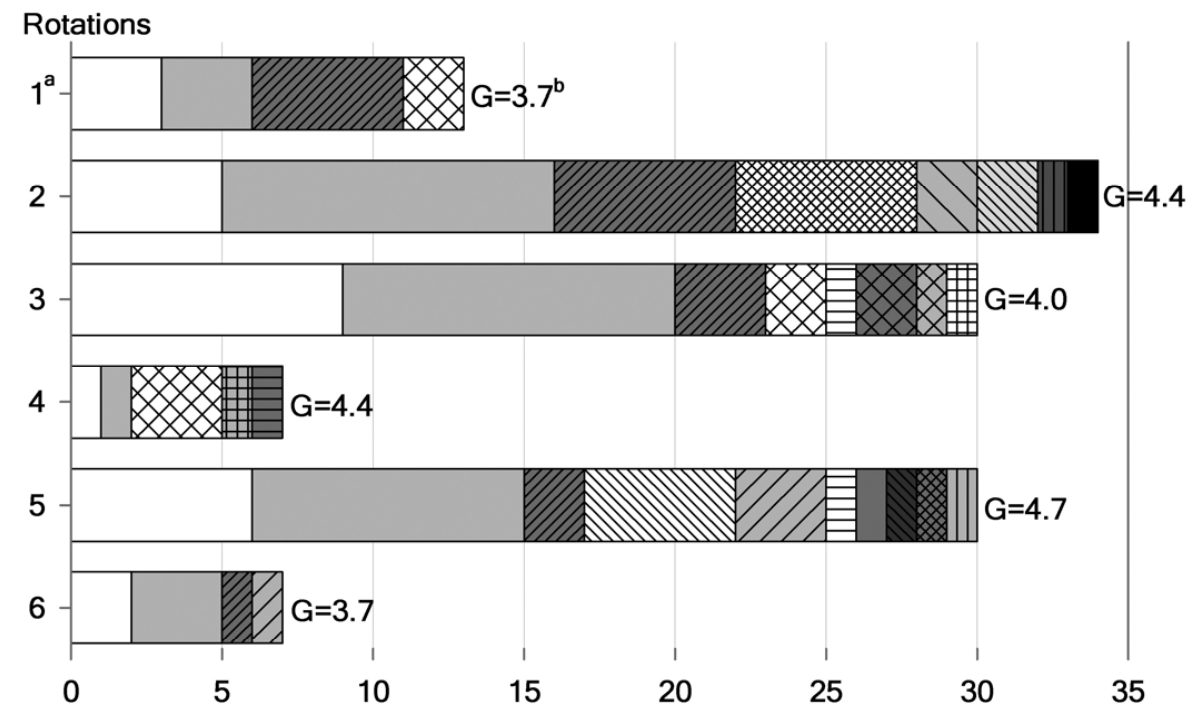

No. SSR genotypes

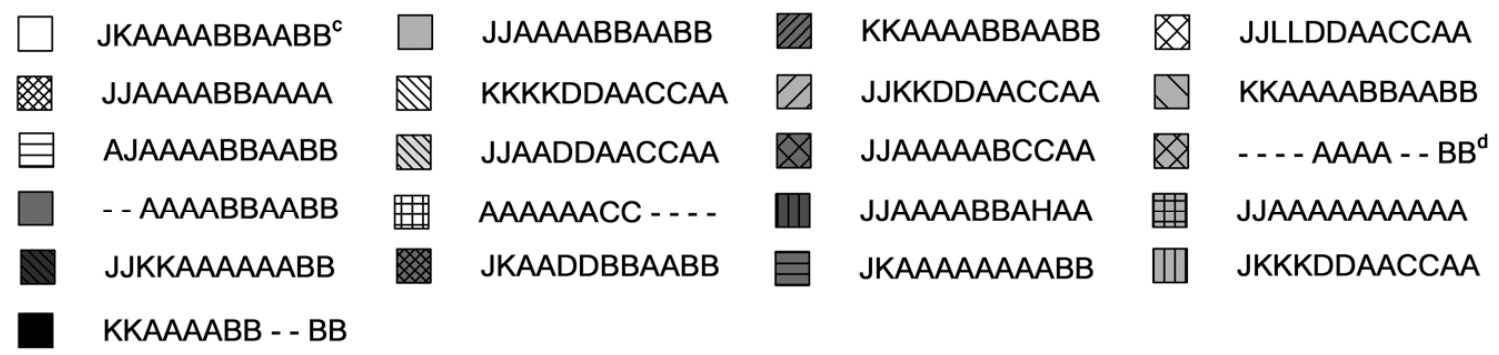

\footnotetext{
a rotation sequences: $1=$ continuous planting of a cultivar with no rps gene; $2=$ annual rotation of a cultivar with no rps and a cultivar with Rps $1 \mathrm{k}$ gene; $3=$ annual rotation of a cultivar with Rps $1 \mathrm{k}$ gene and a partially resistant cultivar; $4=$ four year rotation of cultivars with $R p s 1 \mathrm{k}, 1 \mathrm{c}, 3 \mathrm{a}$ and $1 \mathrm{k}$ gene in year one, two, three and four, respectively; $5=$ continuous planting of a cultivar with high partial resistance; $6=$ continuous planting of a cultivar with Rps $1 \mathrm{k}$ gene.

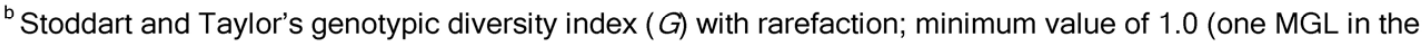
population) and maximum value of 7.0 (all individual with different MGLs).

${ }^{c}$ identical MLG as isolate PR1 used to inoculate the experiment.

d - = no amplification.
}

Fig. 3. Number of multilocus genotypes and their diversity based on eight microsatellite loci of 121 isolates of Phytophthora sojae recovered from soil samples collected from rotations in a 4-year (2007 to 2010) soybean cultivar-rotation study. Genotypes in the figure are based on six polymorphic microsatellites (PS01, PS05, PS10, PS12, PS16, and PS29 [PS24 and PS33 excluded due to monomorphism]). 
the genotypes assessed with the eight SSRs and pathotypes characterized among the 121 isolates recovered from the soil throughout the duration of the experiment.

Segregation ratios for locus PS01. The mean $\mathrm{Ho}$ for the individual loci was 0.000 to 0.267 and was highest for SSR PS01 (Table 7). This particular SSR resulted in an unusually high $\mathrm{Ho}$ (0.267) and low F (0.33) values for a selfing organism such as $P$. sojae. Under complete selfing, the $\mathrm{Ho}$ should be near 0 and $\mathrm{F}$ should be near 1 (24).

The PS01 locus was heterozygous ' JK' in PR1, the isolate that was used to inoculate the experiment. Although the expected F2 monogenic Mendelian segregation ratio is $1: 2: 1$ for a diploid organism, the observed segregation for locus PS01 differed significantly $\left(\chi_{1: 2: 1}^{2}=52.6, P=0.0000\right)$ from the expected ratio in the population as a whole (Fig. 5). Moreover, high and significant $\chi^{2}$ tests were also found among $P$. sojae populations within each year (data not shown). Segregation for PS01 differed significantly from the predicted ratio, with an excess of ' $\mathrm{KK}$ ' genotype and a deficiency of heterozygote 'JK' genotypes. The proportion of heterozygote isolates for PS01 locus recovered during the 4-year period was $14,21,26$, and $28 \%$ from year 1 to 4 , respectively. Interestingly, in the third year of the soybean-cultivar rotation, a third allele, 'A', was determined for PS01 locus in three P. sojae isolates recovered from rotations 3 and 5, with two isolates having an 'AJ' genotype and one an 'AA' genotype (Fig. 6). This allele has 49 6bp repeats, whereas ' $\mathrm{J}$ ' and ' $\mathrm{K}$ ' have 50 and 51 6-bp repeats, respectively. Thus, the new allele had one or two 6-bp repeats fewer than the original 'JK' PR1 inoculated isolate. The corresponding pathotypes for the two heterozygotes isolates 'AJ' were either virulent on Rps 7 (race 1) or virulent on Rps $3 \mathrm{~b}$ and 7 while the homozygote 'AA' was virulent on only Rps 7.

New alleles detected. In total, 10 new alleles (different from PR1 alleles) were detected throughout the 4-year period among six of the eight SSRs. Five new alleles were detected as early as the second year (Table 8) and all were detected on isolates recovered from rotation 5, except for allele size 270 bp from SSR PS29, which was detected on isolates recovered from rotation 2 (Table 8). Throughout the 4-year period, the highest number of new alleles was detected among isolates recovered from rotation $3(n=7)$ and the least in rotation $6(n=4)$ (Table 8$)$ and the highest number of isolates with at least one new allele was recovered throughout the study from rotation $2(n=10)$ and rotation $5(n=12)$ (Fig. 7).

\section{Discussion}

This study examined the effect of deploying Rps genes and partial resistance on the population structure of $P$. sojae. It has long been suggested that resistance genes in the host exert selection pressure on pathogen populations and, consequently, result in selection for virulent pathotypes in the pathogen $(29,49,51,68)$. In this study, we found that changes in pathotype structure were not necessarily a function of the type of resistance being deployed.

Although soil samples collected from three microplots prior to the start of the experiment were positive for $P$. sojae using PCR with $P$. sojae-specific primers, these primers also amplified a simi- lar-size band in the $P$. cactorum control, demonstrating that they might not be $P$. sojae-specific or that PCR conditions needed further adjustments. Similar results were reported using another set of specific $P$. sojae primers, where nonspecific amplification of $P$. drechsleri was obtained when annealing temperature varied by $1^{\circ} \mathrm{C}$ (63). We did not sequence the band that was amplified from the $P$. cactorum control but additional seedling baiting tests were done on the three soil samples that had tested positive by PCR, and we were never able to isolate $P$. sojae. It is also possible, however, that the positive PCRs were, indeed, $P$. sojae but the pathogen was not viable and, thus, could not be baited out of the soil samples using bioassays.

Pathotypes. Although we detected variation in the pathotype profile of the isolates of $P$. sojae that we recovered from the study, significant differences were not observed between rotations $\left(\theta_{\mathrm{PT}}=\right.$ $0.047, P=0.059)$ but, rather, within rotations. In previous reports on the tobacco-black shank pathogen (P. nicotianae) system (57), rotation between cultivars with single-gene resistance and cultivars with a high level of partial resistance not only provided significant

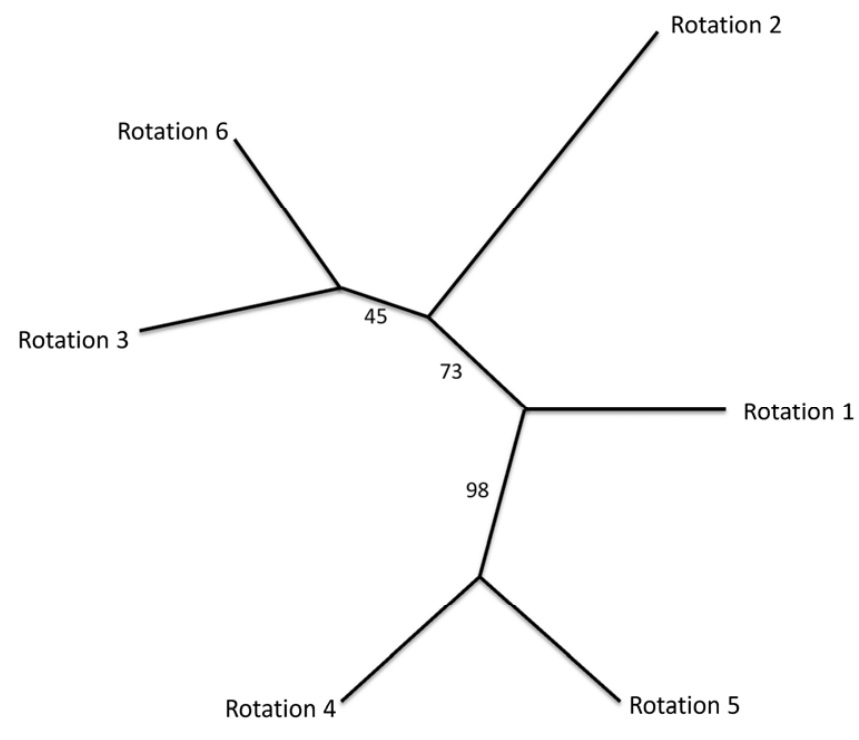

$-10$

Fig. 4. Dendrogram of six populations of Phytophthora sojae recovered from soil samples collected from six soybean-cultivar rotations in a 4-year study (2007 to 2010). The dendrogram was generated by unweighted pair-group method based on the allele frequency of eight microsatellite loci in $P$. sojae. Bootstrap values are shown along the branches. Populations are designated by rotation number, where 1 is continuous planting of a cultivar with no rps gene; 2 is annual rotation of a cultivar with no rps and a cultivar with Rps $1 \mathrm{k}$ gene; 3 is annual rotation of a cultivar with Rps $1 \mathrm{k}$ gene and a partially resistant cultivar; 4 is four year rotation of cultivars with Rps 1k, 1c, 3a, and 1k genes in year one, two, three, and four, respectively; 5 is continuous planting of a cultivar with high partial resistance; and 6 is continuous planting of a cultivar with Rps $1 \mathrm{k}$ gene. Bar indicates Nei's genetic distance.

Table 6. Estimate of differentiation $\left(\theta_{\mathrm{PT}}\right)$ based on eight microsatellite loci among 121 isolates of Phytophthora sojae recovered from soil collected from six soybean cultivar-rotation in a 4-year rotation study $(2007 \text { to } 2010)^{\mathrm{a}}$

\begin{tabular}{lcccccc}
\hline Rotation & $\mathbf{1}$ & $\mathbf{2}$ & $\mathbf{3}$ & $\mathbf{4}$ & $\mathbf{5}$ & $\mathbf{6}$ \\
\hline 1 & $\ldots$ & $\ldots$ & $\ldots$ & $\ldots$ & $\ldots$ & $\ldots$ \\
2 & 0.005 & $\ldots$ & $\ldots$ & $\ldots$ & $\ldots$ & $\ldots$ \\
3 & $0.000^{\mathrm{b}}$ & $0.000^{\mathrm{b}}$ & $\ldots$ & $\ldots$ & $\ldots$ & $\ldots$ \\
4 & 0.217 & $0.380^{*}$ & $0.271^{*}$ & $\ldots$ & $\ldots$ & $\ldots$ \\
5 & 0.029 & $0.120^{*}$ & $0.076^{*}$ & 0.077 & $\ldots .000^{\mathrm{b}}$ & $\ldots$ \\
6 & $0.000^{\mathrm{b}}$ & $0.000^{\mathrm{b}}$ & $0.000^{\mathrm{b}}$ & 0.180 & & $\ldots$ \\
\hline
\end{tabular}

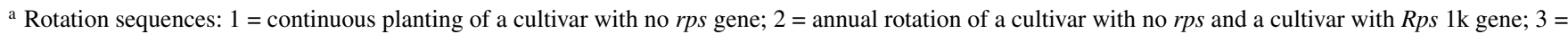
annual rotation of a cultivar with Rps $1 \mathrm{k}$ gene and a partially resistant cultivar; $4=4$-year rotation of cultivars with $R p s 1 \mathrm{k}, 1 \mathrm{c}, 3 \mathrm{a}$, and $1 \mathrm{k}$ gene in year one, two, three, and four, respectively; $5=$ continuous planting of a cultivar with high partial resistance; $6=$ continuous planting of a cultivar with $R p s$ k gene; * indicates significant at probability $P \leq 0.05$, value based on 999 permutations.

${ }^{\mathrm{b}} \theta_{\mathrm{PT}}$ were converted to zero due to negative values. 
reductions in disease incidence and inoculum density but also minimized race shifts in the pathogen. In our study on the soybean- $P$. sojae pathosystem, the effect of single-gene resistance on race shifts in the pathogen was not as simple or delineated. However, there were some similarities detected between the two pathosystems. In the tobacco-black shank pathosystem, low incidence of disease was observed and low inoculum density of $P$. nicotianae detected when continuous single-gene resistance was deployed, and the population shifted from $100 \%$ race 0 at the beginning of the experiment to $76 \%$ race 1 at the end of the 4-year trial (57). In our study, we also recovered fewer isolates of $P$. sojae from the microplots in which continuous single-gene resistance was deployed (rotations 4 and 6) but we also detected the least race shift (Fig. 1). No race shift was observed when $P$. nicotianae was exposed to partial resistance deployed continuously (58); however, in our study, seven new pathotypes were observed when $P$. sojae was exposed to a continuous rotation of a cultivar with partial resistance. Thus, unlike Sullivan et al. (57), we were unable to demonstrate that pathotype shift in $P$. sojae is a function of cultivar rotation. This is probably not surprising because the soybean- $P$. sojae pathosystem is far more complex and diverse than the tobacco-P. nicotianae pathosystem. Although $P$. sojae has more than 200 known pathotypes (14) and 15 resistance genes identified in soybean $(15,23,59), P$. nicotianae has four described races and two single resistance genes identified in tobacco $(45,56)$. Furthermore, $P$. sojae is homothallic and has a very narrow host range (25), whereas $P$. nicotianae is heterothallic and has a wide host range. Thus, the $P$. nicotianae system could be more susceptible to selection pressure from resistance genes $(30,67)$.

SSR genotypes. We detected genetic differentiation among rotations $\left(\theta_{\mathrm{PT}}=0.075, P=0.044\right)$, indicating that isolates of $P$. sojae recovered from some of the rotations were genetically different from each other. With $\theta_{\mathrm{PT}}$ among rotations, we demonstrated that isolates of $P$. sojae recovered from rotations of susceptible cultivars with either Rps $1 \mathrm{k}$ resistance or partial resistance were different from isolates of $P$. sojae recovered from rotations of cultivars with different $R p s$ genes and from isolates recovered from continuous partial resistance. Similarly, the UPGMA analysis separated with high bootstrap the population of $P$. sojae recovered from rotations 4 and 5 from the rest of the rotations.

Baiting methods such as the one used in this study might not be sufficiently quantitative to estimate inoculum density (33); therefore, the number of isolates recovered in the different rotations has limited value and should not be taken as an absolute number but in relation to other rotations. Recovery of isolates with different MLGs was greater under continuous rotation with partial resistance, which was also where $G(G=4.7)$ was the highest and gene diversity $(\mathrm{UHe}=0.45)$ second highest. Moreover, this rotation was where we recovered the highest number of isolates with new alleles, and also where we recovered five new alleles as early as the second year of the experiment. These data indicate that continuous rotation with partial resistance may not be a very effective way to prevent genetic shifts of the pathogen in the soybean- $P$. sojae system. Anderson (3) found that PRR disease severity can be similar after monoculture of partially resistant and susceptible cultivars. He also demonstrated that greater numbers of oospores can be produced in vitro on roots of partially resistant soybean seedlings cultivars than on susceptible cultivars, while fewer are produced in resistant cultivars. If genetic shifts were driven by the numbers of oospores produced (population size) more than by deployment of Rps genes, then this could explain the higher number of MLGs and diversity found in the continuous partially resistant rotation in our experiment. Higher population sizes would enhance the number of mutations or crossovers and increase gene diversity and $G$.

SSRs have a high mutation rate of $10^{-2}$ to $10^{-6}$ events per locus per generation (37), and noncoding DNA are much more tolerant to DNA mutations. Not only SSRs within intergenic regions but also SSRs within genes (protein-coding regions, untranscribed regions [UTRs], and introns) can exhibit a high mutation rate as a

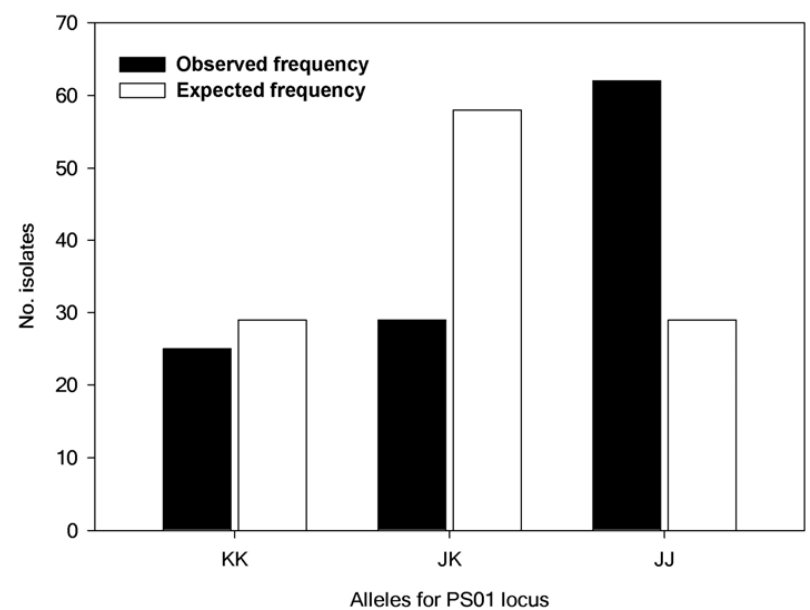

Fig. 5. Observed and expected frequencies for monogenic segregation of alleles within the locus PS01 microsatellite marker of Phytophthora sojae $\left(\chi^{2}\right.$ 1:2:1 $=52.6, P$ $=0.0000$ )

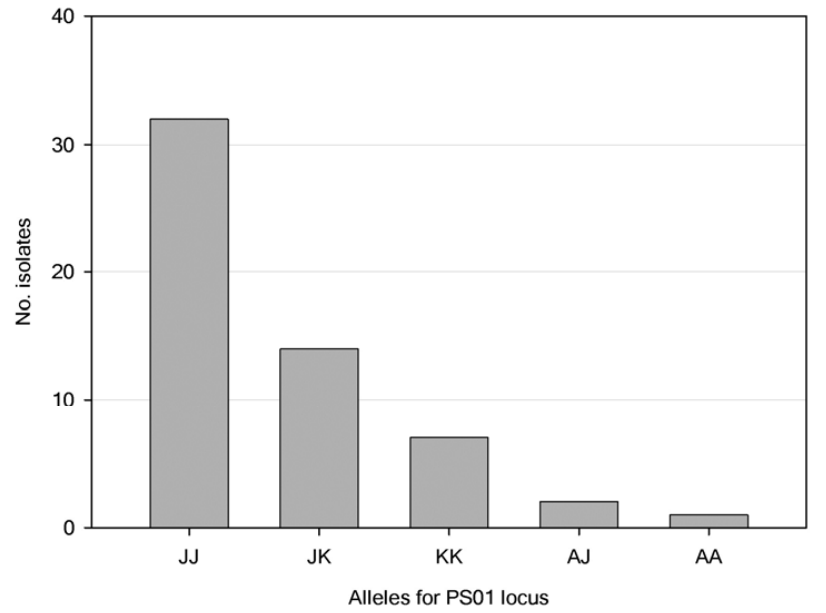

Fig. 6. Observed number of isolates of Phytophthora sojae with different alleles within locus PS01 microsatellite marker in year three of a soybean cultivar-rotation study conducted over a 4-year period (2007 to 2010).

Table 7. Genetic diversity statistics of 121 isolates of Phytophthora sojae recovered from soil of six soybean cultivar-rotation within each of the eight microsatellite loci assessed

\begin{tabular}{|c|c|c|c|c|c|c|c|c|}
\hline \multirow[b]{2}{*}{ Statistic $^{\mathbf{a}}$} & \multicolumn{8}{|c|}{ Loci } \\
\hline & PS01 & PS05 & PS10 & PS12 & PS16 & PS24 & PS29 & PS33 \\
\hline Ho & 0.267 & 0.000 & 0.010 & 0.011 & 0.005 & 0.000 & 0.000 & 0.000 \\
\hline UHe & 0.440 & 0.274 & 0.301 & 0.305 & 0.314 & 0.000 & 0.349 & 0.000 \\
\hline$F$ & 0.326 & 1.000 & 0.940 & 0.961 & 0.964 & - & 1.000 & - \\
\hline
\end{tabular}

${ }^{\mathrm{a}} \mathrm{Ho}=$ observed heterozygosity averaged across rotations; $U H e=$ unbiased expected heterozygosity averaged across rotations, $(2 n / 2 n-1)\left(1-\Sigma p^{2}\right)$, where $p$ is the frequency of the $i$ th allele; $F=$ Wright's fixation index, where $F$ values close to zero are expected under random mating while values close to one indicate inbreeding; and - indicates no $F$ can be calculated for monomorphic loci. 
result of being under stronger selective pressure than other genomic regions (38). Environmental conditions, allele size, repeat motif, and genotype, among several other factors, could affect these mutations at SSR loci (37).

Out of the eight SSRs used in this study, two (PS01 and PS24) were located within gene regions while the remainder were located within intergenic regions (10). PS01 is located in an intron within a gene (Physo_346976) coding for a predicted hypothetical protein LOC10019696, while PS24 is located in the 3' UTR within a gene (Physo_355737) coding for a putative 60S ribosomal protein. Genes coding for proteins such as 60S ribosomal proteins are known to be highly conserved through evolution. Therefore, it is likely that Physo_355737 is also a highly conserved gene with a low chance for any mutation to occur, and this could explain why we did not detect allelic diversity with SSR PS24 in our study (Table 8 ). When SSR PS01 was used, however, we detected one additional allele in 3 of the 121 isolates, which contrasts with the rest of the SSRs (PS05, PS10, PS12, and PS16,PS29), except for PS33, where we detected a higher number of additional alleles.

Most of the new alleles observed in this study seem to have arisen due to a loss or gain of a few or more corresponding repeat motifs. Slip-strand mispairing during DNA replication can result in changes in repeat numbers at microsatellite loci (18). Hence, the changes in the allele sizes we observed may have occurred due to replication slippages that escaped the DNA miss-match repair mechanism. On the other hand, these new alleles could have been present in the genome, with a very low copy number or a frequency and, if favored by the environment, may have increased in copy number or frequency. It is possible that, when the PCR prod- ucts were diluted for SSR analysis, the concentration of these fragments was so low that they went undetected with capillary electrophoresis.

Segregation locus PS01. The excess of genotype 'JJ' for locus PS01 found in the total population may be explained by gene conversion. A high frequency of mitotic gene conversion has been

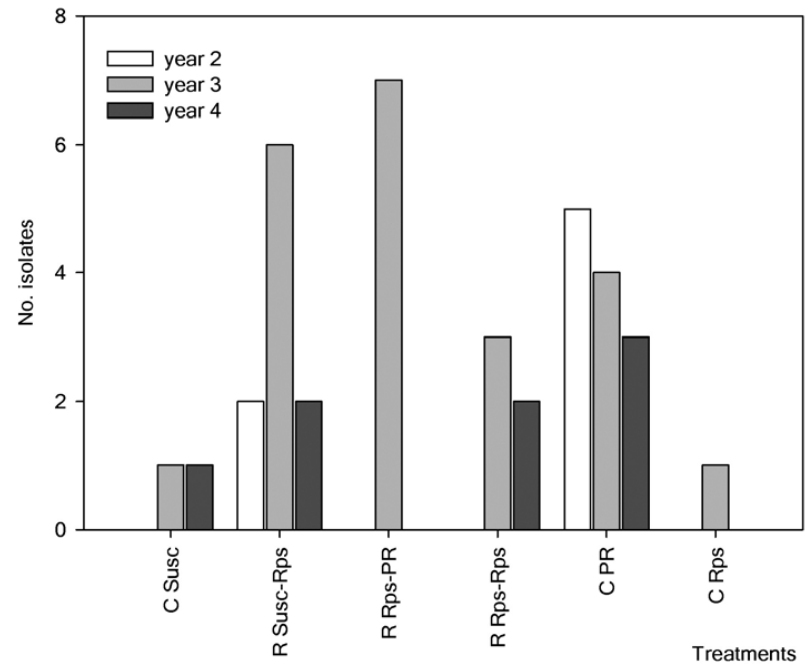

Fig. 7. Number of isolates with at least one new alleles (different from PR1 isolate used to inoculate the experiment) recovered per rotation and per year.

Table 8. New alleles (different from alleles in the isolate used to inoculate experiment) detected using eight simple-sequence repeats (SSRs) on 121 isolates of Phytophthora sojae throughout 4-year soybean-cultivar-rotation experiment (2007 to 2010)

\begin{tabular}{|c|c|c|c|c|c|}
\hline SSR & Allele in PR1 ${ }^{a}$ & New allele & Recovered from rotation ${ }^{b}$ & Number of isolates & Year recovered \\
\hline \multirow[t]{2}{*}{ PS01 } & $425 / 431$ & 419 & 3 & 2 & 3 \\
\hline & & & 5 & 1 & 3 \\
\hline \multirow[t]{5}{*}{ PS05 } & 263 & 339 & 5 & 10 & $2,3,4$ \\
\hline & & & 6 & 1 & 3 \\
\hline & & 343 & 1 & 2 & 3,4 \\
\hline & & & 3 & 2 & 3 \\
\hline & & & 4 & 3 & 3,4 \\
\hline \multirow[t]{6}{*}{ PS10 } & 221 & 191 & 1 & 2 & 3,4 \\
\hline & & & 2 & 2 & 3 \\
\hline & & & 3 & 2 & 3 \\
\hline & & & 4 & 3 & 3,4 \\
\hline & & & 5 & 10 & $2,3,4$ \\
\hline & & 226 & 2 & 2 & 3 \\
\hline \multirow{7}{*}{ PS12 } & 251 & 257 & 3 & 1 & 3 \\
\hline & & 310 & 1 & 2 & 3,4 \\
\hline & & & 2 & 2 & 3 \\
\hline & & & 3 & 5 & 3 \\
\hline & & & 4 & 5 & 3,4 \\
\hline & & & 5 & 10 & $2,3,4$ \\
\hline & & & 6 & 1 & 3 \\
\hline \multirow[t]{7}{*}{ PS16 } & 470 & 405 & 1 & 2 & 3,4 \\
\hline & & & 2 & 2 & 3 \\
\hline & & & 3 & 4 & 3 \\
\hline & & & 4 & 3 & 3,4 \\
\hline & & & 5 & 9 & $2,3,4$ \\
\hline & & & 6 & 1 & 3 \\
\hline & & 475 & 2 & 1 & 3 \\
\hline PS24 & 252 & None & $\ldots$ & $\ldots$ & $\ldots$ \\
\hline \multirow[t]{6}{*}{ PS29 } & 249 & 270 & 1 & 2 & 3,4 \\
\hline & & & 2 & 8 & $2,3,4$ \\
\hline & & & 3 & 4 & 3 \\
\hline & & & 4 & 4 & 3,4 \\
\hline & & & 5 & 9 & $2,3,4$ \\
\hline & & & 6 & 1 & 3 \\
\hline PS33 & 250 & None & $\ldots$ & $\ldots$ & $\ldots$ \\
\hline
\end{tabular}

${ }^{a}$ Isolate used to inoculate experiment. Genotype PR1: 425/431, 263/263, 221/221, 251/251, 470/470, 252/252, 249/249, and 250/250 for SSR PS01, PS05, PS10, PS12, PS16, PS24, PS29, and PS33, respectively.

${ }^{\mathrm{b}}$ Rotation sequences: $1=$ continuous planting of a cultivar with no $r p s$ gene; $2=$ annual rotation of a cultivar with no $r p s$ and a cultivar with $R p s$ 1k gene; $3=$ annual rotation of a cultivar with Rps $1 \mathrm{k}$ gene and a partially resistant cultivar; $4=4$-year rotation of cultivars with $R p s 1 \mathrm{k}, 1 \mathrm{c}, 3 \mathrm{a}$, and $1 \mathrm{k}$ gene in year one, two, three, and four, respectively; $5=$ continuous planting of a cultivar with high partial resistance; $6=$ continuous planting of a cultivar with $R p s 1 \mathrm{k}$ gene. 
previously demonstrated for $P$. sojae (7). This process rapidly converts heterozygous loci to homozygous throughout vegetative growth, and is stimulated by sexual reproduction (7).

A wide range of $P$. sojae races may exist in a natural wild-type population and may only be detected when a resistant cultivar is introduced (28). In our study, no endemic population of $P$. sojae was present, at least not at a detectable level, in the field site where we established the rotations. We introduced a single isolate of $P$. sojae of a known pathotype and recovered three pathotypes fourand-a-half months after inoculation, and a total of 14 pathotypes throughout the 4-year experiment. Moreover, we recovered isolates belonging to 2 MLGs four-and-a-half months after inoculation, and 21 MLGs throughout the 4-year experiment. Because we used SSR analysis to detect genotypic changes that occurred within $P$. sojae isolates recovered from this rotation study, we were unable to determine whether the various pathotypes isolated during the course of the study were descendants of PR1. Moreover, we propose that it is unlikely that isolates of $P$. sojae were introduced into the microplots along with contaminated seed or wind-carried dust, especially because the amount of artificial inoculum used to inoculate each microplot would likely overwhelm the number of $P$. sojae contaminants. Therefore, assuming no or negligible contamination of the microplots from outside sources of $P$. sojae, the most likely explanation for the genetic changes in the isolates of $P$. sojae recovered from soil samples collected from the microplots would be mutation, sexual recombination during selfing, outcrossing, and mitotic recombination. The new allele 'A' detected in locus PS01 may have arisen from a single stepwise mutation (loss of a 6-bp repeat) in allele ' $\mathrm{J}$ ', resulting in a change in size from 425 to 419 bp.

No heterozygosis is predicted in homothallic species of Phytophthora that have been established for more than a few generations, because self-fertilization reduces the amount of heterozygosis by one-half every generation (24). For one locus, however (PS01), our data showed that the proportion of heterozygote individuals tended to increase rather than decrease throughout the study. Although the $\mathrm{I}_{\mathrm{A}}$ suggests asexual reproduction, the high heterozygosity values $\mathrm{(Ho}$ ) we observed in this study suggest that processes other than asexual reproduction and selfing were occurring. Laboratory studies have shown evidence of outcrossing between isolates of $P$. sojae when co-cultured in vitro $(62,65)$. Coinfection of soybean by more than one isolate of $P$. sojae has been demonstrated in greenhouse experiments (35). Co-infection may result in outcrossing between isolates of $P$. sojae that are in close proximity to each other in disease tissue. Although no visible aboveground symptoms of PRR were observed during the 4-year duration of our trial, root rot due to infection by $P$. sojae was not assessed. We suggest that pathogen shifts may have occurred in root infections and in resultant lesions that occurred belowground and were not quantified.

Differentiation during asexual reproduction in $P$. sojae has been known since 1962 (27), and single-zoospore isolates derived from a single zoosporangium have displayed molecular polymorphism and variation in their virulence $(8,27,48)$. A mitotic crossing over and cytoplasmic gene hypothesis has been proposed (52) but the actual mechanism by which this happens remains to be proven. Regardless of the mechanism involved, single-zoospore variability is consistent with random generation of pathotypes from soybean field soils $(13,28,47,51)$, and could reflect the variability obtained in this study. Inclusion of a continuous nonhost rotation control to evaluate random generation of pathotypes in this study would have been useful.

Diversity in the $P$. sojae soil population observed in this study might have been different if PRR had been present and severe in the microplots. Nonetheless, our research has further demonstrated that $P$. sojae has the potential to shift pathotypes or evolve new genotypes very quickly. We were unable, however, to demonstrate that pathotype shift was a function of the Rps gene used. Thus, overuse of an Rps gene does not appear to be the primary reason for changes in pathotype structure of $P$. sojae, nor does continuous rotation with high-partial-resistance cultivars prevent pathotype or genetic shifts.

\section{Acknowledgments}

We thank M. Chilvers and J. Kurle from Michigan State University and the University of Minnesota, respectively, for corrections and suggestions on previous drafts of this manuscript; P. Lundeen for providing the race 1 isolate of $\mathrm{P}$. sojae PR1 that we used to inoculate the experiment; E. Braun at Iowa State University for providing the P. cactorum; and the Iowa Soybean Association for providing funding.

\section{Literature Cited}

1. Abney, T. S., Melgar, J. C., Richards, T. L., Scott, D. H., Grogan, J., and Young, J. 1997. New races of Phytophthora sojae with Rps1-d virulence. Plant Dis. 81:653-655.

2. Agapow, P. M., and Burt, A. 2001. Indices of multilocus linkage disequilibrium. Mol. Ecol. Notes 1:101-102.

3. Anderson, T. R. 1986. Plant losses and yield responses to monoculture of soybean cultivars susceptible, tolerant, and resistant to Phytophthora megasperma f. sp. glycinea. Plant Dis. 70:468-471.

4. Anderson, T. R., and Buzzell, R. I. 1992. Diversity and frequency of races of Phytophthora megasperma f. sp. glycinea in soybean fields in Essex County, Ontario, 1980-1989. Plant Dis. 76:587-589.

5. Barreto, D., Stegman de Gurfinkel, B., and Fortugno, C. 1995. Races of Phytophthora sojae in Argentina and reaction of soybean cultivars. Plant Dis. 79:599-600.

6. Bienapfl, J. C., Malvick, D. K., and Percich, J. A. 2011. Specific molecular detection of Phytophthora sojae using conventional and real-time PCR. Fungal Biol. 115:733-740.

7. Chamnanpunt, J., Shan, W., and Tyler, B. M. 2001. High frequency mitotic gene conversion in genetic hybrids of the oomycete Phytophthora sojae. Proc. Natl. Acad. Sci. USA 98:14530-14535.

8. Chen, C., Huang, L., Buchenauer, H., Zhao, H., Zuo, Y., and Kang Z. 2009. Diversity among single zoospore isolates derived from single-zoosporangia of Phytophthora sojae Kauf. and Gerd. J. Phytopathol. 157:181-187.

9. Dorrance, A., Berry, S. A., Abney, T. S., and Anderson, T. 2005. Isolation, maintenance and evaluation of host resistance to Phytophthora sojae and Pythium spp. in: Plant Health Progress. Online publication. doi:10.1094/ PHP-2008-0118-01-DG

10. Dorrance, A., and Grunwald, N. 2009. Phytophthora sojae: diversity among and within populations. In: Oomycetes Genetics and Genomics: Diversity, Interactions, and Research Tools. K. Lamour and S. Kamoun, eds. John Wiley and Sons, Inc., Hoboken, NJ.

11. Dorrance, A. E., Inglis, A. D., Derie, M. L., Brown, C. R., Goodwin, S. B., Fry, W. E., and Deahl, K. L. 1999. Characterization of Phytophthora infestans population in western Washington. Plant Dis. 83:423-428.

12. Dorrance, A. E., Jia, H., and Abney, T. S. 2004. Evaluation of soybean differentials for their interaction with Phytophthora sojae. Plant Health Progress. Online publication. doi:10.1094/PHP-2004-0309-01-RS

13. Dorrance, A. E., McClure, S. A., and deSilva, A. 2003. Pathogenic diversity of Phytophthora sojae in Ohio soybean fields. Plant Dis. 87:139-146.

14. Dorrance, A. E., McClure, S. A., and St. Martin, S. K. 2003. Effect of partial resistance on Phytophthora stem rot incidence and yield of soybean in Ohio. Plant Dis. 87:308-312.

15. Dorrance, A. E., Robertson, A. E., Cianzo, S., Giesler, L. J., Grau, C. R., Draper, M. A., Tenuta, A. U., and Anderson, T. R. 2009. Integrated management strategies for Phytophthora sojae combining host resistance and seed treatments. Plant Dis. 93:875-882.

16. Dorrance, A. E., and Schmitthenner, A. F. 2000. New sources of resistance to Phytophthora sojae in the soybean plant introductions. Plant Dis. 84:1303-1308.

17. Dorrance, E. A., Berry, S. A., Anderson, T. R., and Meharg, C. 2008. Isolation, storage, pathotype characterization, and evaluation of resistance for Phytophthora sojae in soybean. Plant Health Progress. Online publication. doi:10.1094/PHP-2008-0118-01-DG

18. Eisen, J. A. 1999. Mechanistic basis for microsatellite instability. Pages 3448 in: Microsatellites: Evolution and Applications. D. B. Goldstein and C. Schlotterer, eds. Oxford University Press, Oxford.

19. Excoffier, L., Smouse, P. E., and Quattro, J. M. 1992. Analysis of molecular variance inferred from metric distances among DNA haplotypes: application to human mitochondrial DNA restriction sites. Genetics 131:479-491.

20. Ferguson, M. W. 1987. Epidemic of Phytophthora root rot of soybeans in South Dakota. Plant Dis. 71:850.

21. Ferro, C. R., Hill, C. B., Miles M. R., and Hartman, G. L. 2006. Evaluation of soybean cultivars with the Rps $1 \mathrm{k}$ gene for partial resistance or field tolerance to Phytophthora sojae. Crop Sci. 46:2427-2436.

22. Flor, H. 1971. Current status of the gene-to-gene concept. Annu. Rev. Phytopathol. 9:275-296.

23. Gijzen, M., and Qutob, D. 2009. Phytophthora sojae and soybean. In: Oomycetes Genetics and Genomics: Diversity, Interactions, and Research Tools. K. Lamour and S. Kamoun, eds. John Wiley \& Sons, Inc., Hoboken, NJ.

24. Goodwin, S. B. 1997. The population genetics of Phytophthora. Phyto- 
pathology 87:462-473

25. Grau, C. R., Dorrance, A. E., Russin, J., and Bond, J. 2004. Fungal diseases. In: Soybeans: Improvement, Production, and Uses. H. R. Boerma and J. E. Specht, eds. American Society of Agronomy, Crop Science Society of America, Soil Science Society of America, Inc., Madison, WI.

26. Grundwald, N. J., Goodwin, S. B., Milgroom, M. G., and Fry, W. E. 2003. Analysis of genotypic diversity data for populations of microorganisms. Phytopathology 93:738-746.

27. Hilty, J. W., and Schmitthenner, A. F. 1962. Pathogenic and cultural variability of single zoospore isolates of Phytophthora megasperma var. sojae. Phytopathology 52:859-862.

28. Hobe, M. 1981. Pathogenic Variability of Phytophthora megasperma f. sp. glycinea Isolated from Northwest Ohio Soils. M.S. thesis. Ohio State University, Columbus.

29. Jackson, T. A., Kirkpatrick, T. L., and Rupe, J. C. 2004. Races of Phytophthora sojae in Arkansas soybean fields and their effects on commonly grown soybean cultivars. Plant Dis. 88:345-351.

30. Jiang, R. H. Y., and Tyler, B. M. 2012. Mechanisms and evolution of virulence in oomycetes. Annu. Rev. Phytopathol. 50:295-318.

31. Kaitany, R. C., Hart, L. P., and Safir, G. R. 2001. Virulence composition of Phytophthora sojae in Michigan. Plant Dis. 86:1103-1106.

32. Kennedy, B. L. 1984. Root rot of soybeans in Minnesota: the changing race situation in Phytophthora megasperma f. sp. glycinea. Plant Dis. 68:826.

33. Larkin, R. P., Ristaino, J. B., and Campbell, C. L. 1995. Detection and quantification of Phytophthora capsici in soil. Phytopathology 85:1057-1063.

34. Laviolette, F. A., and Athow, K. L. 1981. Physiologic races of Phytophthora megasperma f. sp. glycinea in Indiana, 1973-1979. Plant Dis. 65:884-885.

35. Layton, A. C., and Kuhn, D. N. 1990. In planta formation of heterokaryons of Phytophthora megasperma f. sp. glycinea. Phytopathology 80:602-606.

36. Leitz, R. A., Hartman, G. L., Pedersen, W. L., and Nickell, C. D. 2000. Races of Phytophthora sojae on soybean in Illinois. Plant Dis. 84:487-487.

37. Li, Y.-C., Korol, A. B., Fahima, T., Beiles, A., and Nevo, E. 2002. Microsatellites: Genomic distribution, putative functions and mutational mechanisms: A review. Mol. Ecol. 11:2453-2465.

38. Li, Y.-C., Korol, A. B., Fahima, T., and Nevo, E. 2004. Microsatellites Within Genes: Structure, Function, and Evolution. Mol. Biol. Evol. 21:9911007.

39. Malvick, D. K., and Grunden, E. 2004. Traits of soybean-infecting Phytophthora populations from Illinois agricultural fields. Plant Dis. 88:11391145.

40. McDonald, B. A., and Linde, C. 2002. Pathogen population genetics, evolutionary potential, and durable resistance. Annu. Rev. Phytopathol. 40:349379

41. Nei, M. 1973. Analysis of gene diversity in subdivided populations. Proc. Natl. Acad. Sci. USA 70:3321-3323.

42. Nelson, B. D., and Hansen, J. M. 1996. Races of Phytophthora sojae on soybeans in the Red River Valley of Minnesota and North Dakota. Plant Dis. 80:104.

43. Nelson, B. D., Mallik, I., McEwen, D., and Christianson, T. 2008. Pathotype, distribution, and metalaxyl sensitivity of Phytophthora sojae from North Dakota. Plant Dis. 92:1062-1066.

44. Niu, X. 2004. Assessment of Phytophthora sojae Race Population and Fitness Components in Iowa. Iowa State University, Ames.

45. Parkunan, V., Johnson, C. S., Bowman, B. C., and Hong, C. X. 2010. Population structure, mating type, and mefenoxam sensitivity of Phytophthora nicotianae in Virginia tobacco fields. Plant Dis. 94:1361-1365.

46. Peakall, R., and Smouse, P. E. 2006. GenAlex 6: genetic analysis in Excel. Population genetic software for teaching and research. Mol. Ecol. Notes 6:288-295.

47. Robertson, A. E., Cianzio, S. R., Cerra, S. M., and Pope, R. O. 2009. Within-field pathogenic diversity of Phytophthora sojae in commercial soybean fields in Iowa. Plant Health Progress. Online publication. doi:10.1094/PHP-2009-0908-01-RS

48. Rutherford, F. S., Ward, E. W. B., and Buzzell, R. I. 1985. Variation in virulence in successive single-zoospore propagations of Phytophthora megasperma f. sp. glycinea. Phytopathology 75:371-374.

49. Ryley, M. J., Obst, N. R., Irwin, J. A. G., and Drenth, A. 1998. Changes in the racial composition of Phytophthora sojae in Australia between 1979 and 1996. Plant Dis. 82:1048-1054.

50. Schimetthenner, A. F., and Bhat, R. G. 1994. Useful methods for studying Phytophthora in laboratory. OARDC Spec. Circ. 143:1-10.

51. Schmitthenner, A. F., Hobe, M., and Bhat, R. G. 1994. Phytophthora sojae races in Ohio over a 10-year interval. Plant Dis. 78:269-276.

52. Shaw, D.S. 1983. The cytogenetics and genetics of Phytophthora. Pages 8194. in: Phytophthora: Its Biology, Taxonomy, Ecology, and Pathology. D C. Erwin, S. Bartnicki-Garcia, and P. H. Tsao, eds. American Phytopathological Society, St. Paul, MN

53. Simons, M. D. 1970. Crown rust of oats and grasses. Am. Phytopathol. Soc. Monogr. 5:47.

54. Stewart, S., Wickramasinghe, D., Dorrance, A. E., and Robertson, A. E. 2011. Comparison of three microsatellite analysis methods for detecting genetic diversity in Phytophthora sojae (Stramenopila: Oomycete). Biotechnol. Lett. Online publication. doi:10.1007/s10529-011-0682-9

55. Stoddart, J. A., and Taylor, J. F. 1988. Genotypic diversity: estimation and prediction in samples. Genetics 118:705-711.

56. Sullivan, M. J., Melton, T. A., and Shew, H. D. 2005. Fitness of races 0 and 1 of Phytophthora parasitica var. nicotianae. Plant Dis. 89:1220-1228.

57. Sullivan, M. J., Melton, T. A., and Shew, H. D. 2005. Managing the race structure of Phytophthora parasitica var. nicotianae with cultivar rotation. Plant Dis. 89:1285-1294.

58. Sullivan, M. J., Parks, E. J., Cubeta, M. A., Gallup, C. A., Melton, T. A., Moyer, J. W., and Shew, H. D. 2010. An assessment of the genetic diversity in a field population of Phytophthora nicotianae with a changing race structure. Plant Dis. 94:455-460.

59. Sun, S., Wu, X. L., Zhao, J. M., Wang, Y. C., Tang, Q. H., Yu, D. Y., Gai, J. Y., and Xing, H. 2010. Characterization and mapping of Rps Yu25, a novel resistant gene to Phytophthora sojae. Plant Breed. Online publication. doi:10.1111/j.1439-0523.2010.01794.x

60. Tooley, P. W., and Grau, C. R. 1984. The relationship between rate-reducing resistance to Phytophthora megasperma f. sp. glycinea and yield of soybean. Phytopathology 74:1209-1216.

61. Tooley, P. W., Grau, C. R., and Stough, M. C. 1982. Races of Phytophthora megasperma f. sp. glycinea in Wisconsin. Plant Dis. 66:472-475.

62. Tyler, B. M., Forster, H., and Coffey, M. D. 1995. Inheritance of avirulence factors and restriction-fragment-length-polymorphism markers in outcrosses or the oomycete Phytophthora sojae. Mol. Plant-Microbe Interact. 8:515-523.

63. Wang, Y., Zhang, W., Wang, Y., and Zheng, X. 2006. Rapid and sensitive detection of Phytophthora sojae in soil and infected soybean by specie-specific polymerase chain reaction assays. Phytopathology 96:1315-1321.

64. Weir, B. S., and Cockerham, C. C. 1984. Estimating F-statistics for the analysis of population structure. Evolution 38:1358-1370.

65. Whisson, S. C., Drenth, A., Maclean, D. J., and Irwin, J. A. G. 1994. Evidence for outcrossing in Phytophthora sojae and linkage of a DNA marker to two avirulence genes. Curr. Genet. 27:77-82.

66. White, D. M., Partridge, J. E., and Williams, J. H. 1983. Races of Phytophthora megasperma f. sp. glycinea on soybeans in eastern Nebraska. Plant Dis. 67:1281-1282.

67. Win, J., Krasileva, K. V., Kamoun, S., Shirasu, K., Staskawicz, B. J., Banfield, M. J. 2012. Sequence divergent RXLR share a structural fold conserved across plant pathogenic oomycete species. PLoS Pathog. 8:e1002400.

68. Yang, X. B., Ruff, R. L., Meng, X. Q., and Workneh, F. 1996. Races of Phytophthora sojae in Iowa soybean fields. Plant Dis. 80:1418-1420.

69. Zhang, X., Scheuring, C., Tripathy, S., Xu, Z., Wu, C., Ko, A., Tian, S. K., Arredondo, F., Lee, M.-K., Santos, F. A., Jiang, R. H. Y., Zhang, H.-B., and Tyler, B. M. 2006. An integrated BAC and genome sequence physical map of Phytophthora sojae. Mol. Plant-Microbe Interact. 19:1302-1310. 